\title{
Charlie Hebdo Attack and Discourses of Muslims in British and Danish Newspapers: A cross-cultural critical discourse analysis of four newspapers
}

\author{
MICHELLE LAWRIE, Robert Gordon University
}

\begin{abstract}
A perceived shift to the right when representing Muslims in the press in Europe has been evident in recent years. Events such as 9/11, the July 2005 London bombings, broader European discussions and mainstreaming of populist discourses have marked a significant shift in the media focusing on Muslims living in Europe.
\end{abstract}

This paper outlines the discourses used to represent Muslims, via conducting multimodal critical discourse analysis. The paper focuses on the 2015 Charlie Hebdo terrorist attack and cross-culturally compares four newspapers in two countries - the UK and Denmark. Results indicate a recontextualisation of the terrorist attack situating the threat within each country, with newspapers positioned as 'left' utilising the same framing and discourses of right leaning newspapers. This situated threat is demonstrated through discourses framing both countries in contrast to Muslim 'values'. Furthermore, both countries focus on utilising Muslim 'voices' who are part of a Star System that are critical of Muslim communities.

\section{KEYWORDS}

media discourse, Muslim representation, multi-modal critical discourse analysis, Charlie Hebdo, UK and Denmark 


\section{Introduction}

The 9/11 attack has resulted in targeted media attention, scrutiny and focus on Muslim communities in Europe (Rytter and Pedersen 2014). Significant events following 9/11 such as terrorist attacks in parts of Europe, broader debates about Muslims and the murders of Pim Fortuyn and Theo van Gogh have aided in the rise of right-wing populism in Europe. This rise has resulted in a homogenous Othering of Muslims in contrast to a heightened focus on the perceived indigenous 'people' or 'renationalization' within a nation across Europe (Wodak $2015,1)$. The media constructing of viewing Muslims through a 'multicultural visibility' lens and a general questioning of multiculturalism in Europe have been sustained by 'cluster events'. Furthermore, the constant media reporting and 'threat' framing of Muslim communities following these events have constructed and 'intensified[...]concerns' of Muslims (Cihodariu and Dumitrescu 2013, 53).

Leaders such as Sarkozy and Cameron have contributed to the focus on Muslims and legitimisation that multiculturalism has failed "via a "permissive signal"' (Lesinska 2014, 3839). The discursive linking of Muslims, multiculturalism and terrorism has become a focal point in populist rhetoric and subsequently mainstreamed in politics and the media. Thereby this discursive linking has further legitimised media scrutinization and construction of Muslims as suspect. Emma Hanes and Stephen Machin (2014) found a rise in hate crime towards Muslims after a terrorist attack has occurred in the West. In combination with the dialectical relationship between the media and politics, as demonstrated with the rise of right-wing populist rhetoric becoming normalised in media discourse, shows the necessity of examining media discourse on Muslims (Fairclough 2001).

The heightened media focus on Muslims post 9/11 has resulted in the framing of Muslims as linked with terrorism and is increasingly normalised within the media, particularly following events such as Charlie Hebdo (Sultan 2016). Therefore, it is evident that negative Othering of Muslims is a Europe-wide phenomenon (Wodak et al. 2013; Wodak 2015) with concern expressed by organisations and academics in the UK and Denmark (see Sian et al. 2012; Hervik 2012; Keskinen and Andreassen 2017). However, variations in Muslim media representation is context dependent within Europe (Caviedes 2015). Consequently, there is a need to examine and compare Muslim media discourses cross-culturally. Saifuddin Ahmed and Jörg Matthes (2017) have outlined examining Muslim media representation 'cross-nationally' as increasingly essential to further the field of media representation studies. 
This paper focuses on discourses about Muslims within media reporting, in four newspapers, on the Charlie Hebdo terrorist attack of $7^{\text {th }}$ of January 2015 where two gunmen killed 12 staff from Charlie Hebdo and injured 11. Amongst the dead were cartoonists, editors, maintenance workers, police officers and guests (Withnall and Lichfield 2015).

Multimodal critical discourse analysis is used on four newspaper opinion pieces from The Guardian, The Telegraph, Jyllands-Posten and Politiken who covered the attack over two weeks. The paper argues that the event is recontextualised to focus on the incompatibility of Muslims living in each country. Furthermore, Muslims who are critical of the Muslim 'community' are utilised in texts to justify negative representations of Muslims and legitimise discourses of the status quo. The research contributes to cross-cultural media representation of Muslims, with the inclusion of examining representation through Gullestad's Star System theory. Moreover, the paper contributes to mediation literature on Muslims. This paper uses a cluster event and developed theory taken from my $\mathrm{PhD}$ thesis (Lawrie, 2019).

\section{Press Reporting on Muslims}

Previous research has been conducted focusing on media representation of Muslims. Paul Baker et al. (2013) found from a corpus analysis covering 1998 - 2009 of British press reporting that Muslims are increasingly linked with extremism and represented through negative Othering. Similarly, Kerry Moore et al. (2008) examined reporting of Muslims through content analysis and some critical discourse analysis on the British from $2000-2008$. Findings indicate that Muslims are increasing discursively linked to acts of terrorism. However, their approaches did not filter stories that focus on national identity, which this study did. Edward Said (1997), Elizabeth Poole and John E. Richardson (2006) and Ferruh Yilmaz (2011), for example, offer more generalised examinations on Muslim representation within the media. However, this paper narrowed the focus on examining if national identity and multiculturalism in each country are referred to when constructing discourses on Muslims following a specific cluster event.

Media reporting on Muslims following Charlie Hebdo has also been examined previously; Des Freedman (2017) focuses on the recontextualization of Charlie Hebdo as an issue of freedom of speech which is similar to the media framing of the Muhammad Crisis of 2006 (Hervik 2018 and Boe 2017). Desislava Cheshmedzhieva-Stoycheva (2015) cross-culturally examined newspaper articles from Bulgaria and Britain for over two months following Charlie Hebdo. Results indicated that both countries attempted to portray a positive representation of Muslims. 
However, the newspapers analysed were more left-leaning, unlike this study, which focuses on examining newspapers from both spectrums. Juan Liu and Ashik Shafi (2019) analysed British and American newspaper coverage of the Charlie Hebdo attack through content analysis and survey data and found freedom of speech a dominant framing. Other studies have focused more generally on outlining Charlie Hebdo and subsequent press reporting as the result of the normalised racism and xenophobia against Muslims (Bertelsen and Zagato 2015) and a dominant focus on the reporting of Muslims (Sreberny 2016). However, no paper has examined and compared cross-culturally press reporting on Muslims by the British and Danish press following the Charlie Hebdo attack.

Dominant discourses of constructing an incompatibility with the West and linking Muslims with violent acts through an Orientalist lens has resulted in negative Othering of Muslims is Europe and Western wide (Benzehaf 2017). An Oriental discourse is the means of creating an imaginary Other between the East and West to promote European power and differentiation (Said 1995). It constructs a positive identity of the West and presents Muslims as 'barbaric', homogenising Islam as a 'malevolent and unthinking essence' linked with terror and extremism (Said 1997, 8). The media construct Muslims, through a mix of clash of civilizations and orientalist discourse whereby Muslims are framed as having an 'Islamic' viewpoint on everything (Karim 2011).

The Western media represent Muslims through a 'globalised discourse' combining Orientalism and xenophobic discourses and focusing on a moral panic of the Muslim Other as uncivilized (Dagistanli and Grewal 2012, 119). These discourses are employed to justify antimulticulturalism stances. Additionally, this is evident in both the Danish and British press (Kublitz 2010; Richardson 2004). Orientalist discourse constructs a discursive difference between the 'unenlightened outsiders' Muslims and the West (Morey and Yaqin 2011, 1). Although media discourse is constructed to be interpreted as 'common sense' it is 'largely ideological' in preserving the status quo (Talbot 2007).

Despite many European countries being well established multicultural nations, the focus in the media remains on the cultural incompatibility of Muslims through an ' $U s$ ' versus 'Them' dichotomy (Gemi et al. 2013). A fear-inducing anti-Muslim and anti-immigrant frame has been created within European media focusing on multiculturalism or multicultural aspects within a nation and the loss of national identity (Lesinska 2014). This is also evident in the UK and Denmark and has been partly influenced by the rise of right-wing populist parties, which has affected mainstream politics and media reporting on Muslim communities. Examples of 
this are the success of UKIP (an anti-immigrant, anti-Islam and anti-Europe party) in 2004 and 2009 European Elections (Hayton 2010; Sheets et al. 2015); and the Danish People's Party (DPP hereon) entering mainstream politics in 2001 Danish general election. A further Danish example includes the subsequent negative focus of Muslim immigration and framed 'struggle to reclaim Denmark from a political elite' following DPP entering mainstream politics (Hervik 2012, 212). The rise of right-wing populism has emerged as a result of an ethno-national focus, through cue expressions, implicitly 'stressing difference' of Muslims (Wodak 2015, 54; Inglehart and Norris 2016). National 'markers' are used implicitly through banal nationalism deictic words such as 'we' and 'us' (Billing 1995). The Us v Them dichotomy functions as a primary focus in constructing the conspiracy theory of the political elite favouring the rights of Muslims over of the 'indigenous' (Stoica 2017).

In the British media, the framing of Muslims as culturally different through an Us and Them lens has been constructed following focus on multiculturalism as 'the weakest link in British national identity' (Morey and Yaqin 2011, 77). Events such as the July 2005 London bombings (7/7) have led to the 'Othering' of British Muslims (Poole 2011), through discursively linking terrorist attackers with the wider Muslim community.

Within Denmark, the media have predominantly employed a clash of civilizations discourse, focusing on freedom of speech, and the 2005/2006 Muhammad Cartoons succeeded in pushing this discourse to the forefront of public debate (Bødker 2009). Further expansion of 'multiethnic' neighbourhoods framed as 'ghettos' is constructed in the media as sites of 'bad integration' (Jensen 2015). Debates on Muslims are focused on cultural difference, a threat to national security and the loss of national identity.

Although this paper focused on print newspaper articles, it should be noted that there is an increasing need for examining the fast-growing online news medium, as recommended for future research (Bergström and Belfrage 2018). However, Marina Ghersetti (2014) and Thorsten Quandt (2009) found no differences between print and online contents of newspaper articles. Nevertheless, the paper examines print newspaper articles and tools used to construct discourses on Muslims.

\section{Star System}

A Star System has developed in the media, as a discursive tool, to forefront and present views of minority women who are critical of 'their' Muslim and Islamic communities as 'Western' (Gullestad 2006). The Star System theory developed from Virginia R. Dominguez's (1994) 
initial finding focusing on race inclusion within the Academy in America in the 1990s introduced to 'counter historical patterns of exclusion based on racial classification' (333). Dominguez found the Academy created a 'star system' of ethnic minority academics hired to demonstrate diversity within Universities. The 'star system' functioned not to promote diversity but to control visible differences between white and black academics further. The theory has overlapped into media research to highlight the employment of the Star System of 'diversity' within the media. Gullestad (2006) outlines minority women who censor their minority, are 'superprivileged' (ibid: 50) by the media to 'confirm' dominant negative discourses of Muslims while constructing an image of the press promoting diversity of voices.

This theory proved essential for the analysis of this paper, which found 'Muslim' voices who were critical of the Muslim communities were utilised in articles to legitimise negative representations of Muslims.

\section{Method}

This paper conducted a comparative study of the British and Danish media, of Muslim representation in reporting of, and following the Charlie Hebdo terrorist attack in Paris, France, 2015. The Charlie Hebdo attack was chosen to analyse to build on previous literature examining media discourses on Muslims during 'cluster events' (see for example Alghamdi 2015; Hervik 2014; Weaver 2010; Vliegenhart and Boomgaarden 2007 and Andreassen 2007). Furthermore, the significance of the Charlie Hebdo attack on media discourse has been acknowledged as contributory in normalising negative representations of Muslims (Hjarvard and Lundby 2018 and Freedman 2017).

\section{Research Question}

The paper focuses on discourses used about Muslims in media reporting within selected newspapers after the Charlie Hebdo attack. The following sub-questions for the research were:

1. What discourses are utilised to represent Muslims in the British and Danish newspaper articles?

2. What framings are used within discourses to represent Muslims in the British and Danish newspaper articles?

3. Is national identity utilised to represent Muslims, if so, how? 
4. Are references made to multiculturalism in each country?

The research questions developed from engagement with existing literature around the dominant framings and discourses the media employ when discussing Muslim communities (see Vertovec and Wessendorf 2010; Wodak 2015; Allen 2015; Billig 1995 and Poole 2011, 2014). These research questions aided in formulating the methodology for selecting and filtering the corpus.

In total, four texts, all opinion pieces, were analysed from four newspapers. The newspapers used were; The Telegraph and The Guardian from the British press and Jyllands-Posten and Politiken from the Danish press ${ }^{1}$. A mix of left and right leaning newspapers was required to determine if political stance would influence Muslim representation, as has been found in previous research (see Jacobsen et al. 2013 and Fryberg et al. 2012). Texts were retrieved from the Danish media database InfoMedia and British texts were retrieved from International Newsstand and LexisLibrary. All texts are available online.

Texts were gathered over two weeks from $7^{\text {th }}-22^{\text {nd }}$ of January. Thereon texts were filtered through a stratification system ${ }^{2}$ To narrow the comparative element to four texts to focus on producing multiple textual evidence. The paper utilised critical discourse analysis using Fairclough's three-dimensional framework (1992). The primary analysis was on the textual level with a focus on 'cue' words/phrases and framings, although discursive and social practices dimensions are referenced. Criticism of critical discourse analysis outlines the need for more textual evidence, and therefore, the focus of the paper is on the textual level (Breeze 2011; Stubbs 1997).

Textual analysis in the form of multi-modal critical discourse analysis was used, including a Barthes inspired semiotic analysis of three images selected from the texts. The images analysed were chosen to outline the representation of newspapers' use of binary opposition depicting Muslims as Other. Furthermore, the addition of analysing some images from the articles are in part, a response to Ahmed and Matthes' (2017) call for media representation on Muslims to include more visual analysis.

\footnotetext{
${ }^{1}$ Danish texts were translated and interpreted by the researcher who has a background in Danish.

2 Texts were required to refer to Muslims in general, national identity and reference, implicitly or explicitly, multiculturalism in each country. These stratification requirements were formulated from common themes used concerning Muslim representation, such as multiculturalism, evident in previous literature.
} 


\section{Analysis}

Four texts were analysed and the main discourses found were; Orientalism and Clash of Civilizations, these were presented in a right-wing populist framing of fear of 'the' Muslim Other. The analysis for both countries is structured under discourse headings and framings. All texts recontextualise the attack to situate the threat of terrorism within each country, which is linked to the Muslim community's lack of integration and understanding of their constructed 'host' country.

\section{UK}

The UK newspapers focus on using an Orientalist discourse within three frames - they are Muslim victimhood identity, blaming the political elite and binary opposition of an enlightened West versus barbaric Muslims. The framings all contribute to creating an 'Other' representation of Muslims. Furthermore, national identity is employed, constructing an 'indigenous' UK representation, in opposition to Muslims.

\section{Orientalism \& Muslim Victimhood Identity}

The Telegraph article 'When will the safety of innocent civilians - of all faiths and none - be put before the human rights of maniacs?' by Allison Pearson focuses on creating an Orientalist binary opposition of an 'enlightened West' and 'barbaric', 'childish' Muslims. This is to be expected as Pearson, a columnist, is known for her framing of Muslims against liberal ideals, particularly during the Jack Straw veil debate (Meer et al. 2015). The text focuses on the Charlie Hebdo attack survivors who are framed as having 'forgiven' the attackers by creating the cartoon 'I am Charlie'. This framing is in opposition to the attackers who chose to react in 'anger'. However, this representation is extended to the wider Muslim community in the UK who; 'lash out like angry children', they are 'childish' and will not acknowledge they are 'part of the problem' (Pearson 2015). Muslims are framed as 'offended' and 'hurt' by the Charlie Hebdo cartoons and being intolerant. This functions as part of a Muslim Victimhood identity framing which is part of the Orientalist discourse. Legitimisation is created by quoting Sara Khan, director of Inspire, who has supported the Prevent strategy, a major contributor in constructing Muslims as 'suspect' (Qurashi 2018). Khan states the reaction by Muslims towards the cartoons is "the Muslim "grievance narrative"" (Pearson 2015). Khan is used as a Star System member with a critical voice on Muslims living in Europe, via a homogenous grouping of Muslims stating that they live in; 
'European nations that afford them remarkable freedoms and benefits' however 'insists on seeing themselves as forever oppressed by the West' (Pearson 2015)

Similar to The Telegraph, The Guardian text 'After the Paris attacks we're in danger of abandoning the right to offend' by Natalie Nougayrède, also uses Orientalism to frame Muslims as collectively 'angry' consistently. This is achieved with intertextual reference to Jyllands-Posten 2005 publication of the Muhammad cartoons. The Guardian focuses on the fake cartoons, which Jyllands-Posten did not create, that imams presented in the Middle East, this was 'intended to arouse hatred and anger', which led to 'violent incidents' and 'dozens of deaths' (Nougayrede 2015). This intertextual reference recontextualises the Charlie Hebdo attack to frame Muslims as violent, and manipulative. The text highlights that Muslims will use 'deliberate manipulation' of facts to cause anger because of 'sensitivities'.

Similarly, this is, like The Telegraph's framing of Muslims, part of a Muslim Victimhood Identity. Again, like The Telegraph, The Guardian uses right-wing populist framing by focusing on the liberal left who are preventing freedom of speech and allowing terrorism by not challenging 'issues' within the Muslim community (Freedman 2017). The Guardian frame the left as 'guided by[...]colonial guilt' (Nougayrede 2015).

Colonial guilt is an interpretive and nationalist 'cue' (Fairclough 1989 and Billig 1995) that the text producer is referencing Muslims. The left is permitting Muslims to be 'sensitive' in criticism because of their 'guilt', and this is negating the right of freedom of speech. 'The right to offend', or freedom of speech, is 'in danger' from the liberal left and Muslims. The text producer utilises right-wing populist rhetoric and banal nationalism of a British ' $U s$ ' and minority 'Them' to strengthen their argument of the 'danger' to freedom of speech. Nougayrede are 'struck by the argument';

'that we should be especially sensitive to the views of minorities, or any group perceived as weak[...] should they infringe our free choices in a democracy?' (Nougayrede 2015)

Despite The Guardian being left-leaning the text aligns with the rise and mainstreaming of populist rhetoric around Muslims.

\section{Orientalism - Blaming the Political Elite}

Similarly, The Telegraph also focus on the liberal left, explicitly blaming them for the attack. There is intertextual referencing through listing media events and news of forced marriage, segregation in schools and female genital mutilation that 'we' (Brits) are 'fed up' of hearing 
(Perason 2015). The text claims to represent 'non-Muslim Britons' 'cue' of ethno-nationalism, populist rhetoric, and of speaking for 'the people' (Wodak 2015). The text continues that nonMuslims are 'fed up' and 'despise' the 'cowardly political class' that 'tip-toed around 'cultural sensitivities' (Pearson 2015). These examples are used to link Orientalist discourse with the framing of the political elite allowing the 'Orientalist' practices to happen in the UK. The framing alludes that this is because they are afraid of offending Muslims who are discursively linked as part of the prevention of freedom of speech and potential terrorism in the UK. References to these practices being non-British are demonstrated when referring to a Muslim girl who has been raped by men in 'her community', the author states;

'how dare they come here and recreate their primitive, peasant society in this enlightened land?' (Pearson 2015)

Security discourse is used intertextually to include a video of Abu Hamza or 'Captain Hook', which the British media has nicknamed him, who was found guilty of terrorism in the USA. The video documents his years of working in terrorist groups; the images from this video reinforce the Orientalist discourse of angry, barbaric Muslims. This further reinforces the rightwing populist rhetoric of 'feeble' British political elite not protecting Britain from terrorism. Furthermore, in comparison to a video used at the end of the article, the two images reinforce the Orientalist binary opposition of enlightened West and barbaric Muslims.

\section{Orientalism - Binary Opposition Enlightened West v Barbaric Muslims}

The Telegraph's focus of Abu Hamza to frame the left as tacitly supporting terrorism, while negating the promotion of freedom of speech, additionally creates a binary opposition between the West and Muslims. Image 1 reflects this and on a denotative level has three men shown as holding onto a beige car. The men are each wearing a headpiece; they all appear to be laughing, smiling and shouting. One man to the left is holding a semi-automatic rifle, the man next to him is wearing a bandolier and the man to the forefront is carrying a semi-automatic rifle on his back. Image 2 denotatively shows three white men sitting at a table. The man to the lefthand side is looking and facing a man in the middle; he is holding a microphone and is wearing glasses and a brown suit. The man in the middle is wearing a black leather jacket; he has his head down and his face is not visible. He is using his left hand to hold his head, and his right hand is touching a microphone lying on a table on top of what appears to be a newspaper with a green front cover and white font. The third man to the right-hand side is wearing a black suit with a white shirt, he is facing the man in the middle and has his right arm on the man's shoulder, he appears to be leaning towards the man in the middle. 
The Abu Hamza video is in binary opposition to the Charlie Hebdo video where the use of the crying cartoonist shows the emotion or humanness of the West, expressed in the cartoonist and his creation of 'I am Charlie' connoting 'we are all Charlie'. The cartoonist Renald Luzier discusses forgiving the attackers while being visibly upset. This display of vulnerability and emotion reinforces the 'enlightened West', ready to forgive discourse by in contrast with the intertextuality of Abu Hamza 'Captain Hook'. Hamza is represented as what the left have permitted Muslims to 'do' in the UK, fostering 'primitive' practices such as segregation in schools.

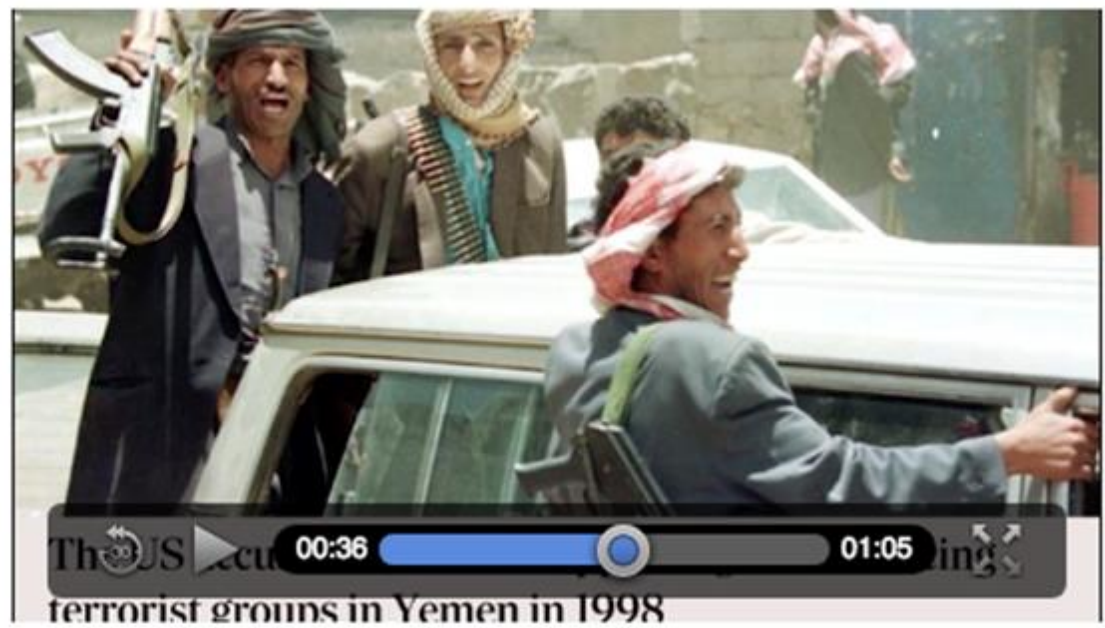

Image 1: Video still, Telegraph (Telegraph Media Group Limited 2015)

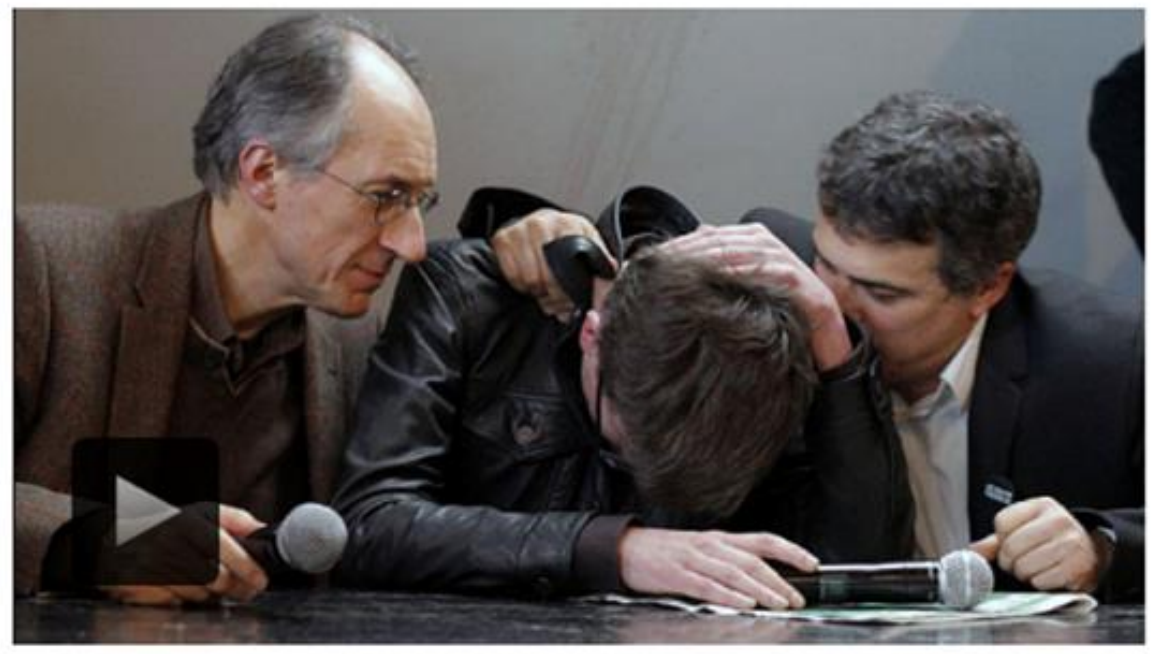

Image 2: Video still, Telegraph (Telegraph Media Group Limited 2015)

This is intended to discursively link Hamza with 'barbaric' Muslims immigrants, not demarked from the wider Muslim community, referred to in the article. This further eludes to the Christian 
religion and prominence of forgiveness, reinforcing the Western framing and Othering of Muslims from the mainstream Western religion.

\section{Denmark}

The Danish texts use a Clash of Civilizations discourse with further sub-discourses focusing on: fear, Muslims as a suspect community, and like the UK texts create a visual binary opposition demarcation between angry Muslims and democracy. Similarly, like The Telegraph, Jyllands-Posten also utilises Star System members to justify negative Otherisation of Muslims.

\section{Clash of Civilizations - Fear Discourse}

Fear of violence within a Clash of Civilizations discourse is focused on in Jyllands-Posten text 'We can't just pretend it is not Muslims' by Lasse Lavrsen and Martin Kaae. The text includes quotes from several Muslims confirming that there is a need for 'us'; to examine Islam and Muslims. Naser Khader, a Conservative Danish MP is quoted as saying that Muslims need to be vocal about denouncing terrorism. He states there is:

'a need for a complete fundamental cultural war inside the Muslim house' (Lavrsen and Kaae 2015)

The 'Muslim house' creates a static, homogenous representation of Muslims who are in a 'culture war'. The metaphor of 'cultural war' connotes that there is an inherent problem, a cultural norm of terrorism, within 'the' Muslim community discursively linking Muslims with terrorism. Quotes from Professor Emeritus Mehdi Mozaffari, author of a book on Islamism in 2013, cue Mozaffari as an authority on the topic. These quotes are utilised to legitimise the linking of Muslims with terrorism. Mozaffari is quoted that 'violence is part of Islam', therefore an extension of all Muslims.

Furthermore, fear and suspect community discourses are discursively linked with Muslims through comparisons between Islam and Nazism. This is achieved by quoting Khader, a Star System member, who suggests that Muslims are the solution to extremism. Muslims need to 'distance themselves from terrorism'; Khader states it is:

'your problem [Muslims] more than it is the Danes problem[...]You have a problem as a Muslim if you do not say "not in my name"' (Lavrsen and Kaae 2015)

Tacit support for terrorism from Muslims is implied in this framing as the problem and solution in tackling terrorism, which Jylllands-Posten frame as part of Muslim culture. This framing 
and discourse from Jyllands-Posten are no surprise considering the newspaper's history of negative Muslim representation, from campaigns against Somali refugees to the publishing of the Muhammad cartoons (Hervik 2012).

\section{Clash of Civilizations - Star System}

This utilisation of Star System members within Jyllands-Posten functions within a Clash of Civilizations discourse. The headline 'We can't just pretend it is not Muslims' by Lavrsen and Kaae 2015 uses banal nationalism with the use of the word 'we'. Quotes from Ayaan Hirsi Ali, a Star System member, who, along with 'Danish experts' all 'agree' that the Quran was the terrorists' inspiration thus supports the headline. Furthermore, the headline creates an image of a 'clash' between Islam and the West because it homogenises Muslims who follow the same ideals or 'ideology' as Islamists. This is legitimised in the statement that 'a row of experts' (cue for 'truth') in religion and politics have confirmed it is 'not possible' to separate the terror attacks from Islam. The number of experts quoted is not stated, however, the metaphor of a 'row of experts' functions to legitimise the discourse because it is 'confirmed' by many experts. The experts 'underline' that;

'the terrorists follow an extreme version of Islam, but this is based on a religion practiced worldwide by 1.6 billion Muslims' (Lavrsen and Kaae 2015)

Teun A. van Dijk (1992) outlines the word 'but' is often employed when xenophobic discourses are utilised because it negates what was previously stated. The 'suspect' lens, therefore, is on Muslims 'worldwide' because they practice the same religion as the extremists. Thereby this creates a binary opposition of a 'clash' between the West and Muslims through discursively linking and framing all Muslims as potential terrorists. Importantly, there is an attempt to demark Muslims from terrorists by stating that not all Muslims be blamed for terrorism. However, the legitimising use of quotes from 'experts' is again employed in the next paragraph reinforcing that Islam cannot be separated from terrorism. This reiterates that it is a problem with Muslims and Islam and is further evident in Politiken.

\section{Clash of Civilizations - Suspect Community}

Constructing Muslims as a suspect community is dominant in Politiken's article 'Whilst We Wait' by DPP member, Mogens Camre. Muslims living in Denmark are linked with terrorism because they are framed as part of a 'problem', have culturally different values and the left have 'allowed' 'them' to remain 'different' in Denmark. There is linking of recent settlements 
of non-Western immigrants in the overall framing that the movement of people into Denmark will ultimately lead to a terrorist attack. The article states;

'we can't continue to house humans who reject our fundamental values' (Camre 2015)

Framing Muslims as being against the constructed 'indigenous' 'values' is employed more in the Danish newspapers than the British newspapers utilising the discourse. The 'cue' word, and Danish idiom, 'house' establishes a need to examine the 'issue' of immigration from nonWestern countries, framing all Muslims as immigrants. Further framing of Muslims as immigrants is indicated when Camre states:

'we cannot have foreigners in this country, who are against democracy' (Camre 2015)

The word 'foreigners' in the excerpt translates to 'fremmede' in Danish; this is significant as in Danish two words can be used to mean 'foreigner' - 'udlænding' and 'fremmede'. This is linked with radical right-wing populist parties' rhetoric who have been found to use the xenophobic use of the word 'Fremmede' in Denmark and Austria (Boreu 2013). On a discursive level it must be acknowledged that Mogens Camre, the text producer, has voiced negative opinions about Islam and Muslims overall who he cites 'cannot be integrated' (Holtug 2011, 109). There is further focus on the incompatibility of Muslim 'values' against Danish 'values' with intertextual referencing of a Muslim woman debating headscarves on DR (Danish television network) who supports:

'the culture of the oppression of women' (Camre 2015)

This is framed in contrast against Danish 'values' which are implied as incompatible because they cannot both be supported.

Although Politiken is a traditionally left-leaning newspaper the collaboration with Camre to produce the article demonstrates the normalisation of negative Muslim Othering and mainstreaming of populist rhetoric in the media (Wodak 2015; Hervik, 2012). Moreover, the article reflects the influence of DPP on Danish society including politics, the media and changing media landscape in Denmark towards increased collaboration with politicians to widen the readership (Blach-Ørsten in Kuhn and Nielsen 2014).

Use of the Clash of Civilizations discourse is further exemplified in the utilisation of an image in the text, creating a binary opposition between Muslims and Denmark. 


\section{Clash of Civilizations - Binary Opposition of Angry Muslims versus Democracy}

A binary opposition of angry Muslims versus Democracy ('cue' word for Danish identity) is reinforced with the inclusion of an image to legitimise the Clash of Civilizations discourse.

Image 3 shows a grey/blue shadow covering a man holding the gun and aiming towards a 'democracy' sign. This connotes that he is coming out of the darkness in reference to the overall narrative of Denmark being the next target. This is reinforced with the headline 'Whilst We Wait' because society has allowed democracy to be attacked for too long. Therefore, terrorism is coming out of the darkness, which additionally represents this darkness is already present in Denmark and emerging out into the light. This reinforces the incompatible of Islam with the West or Denmark, because it is 'angry' or threatening to 'democracy' or Danish identity. The shadow around the man holding the gun constructs the myth of the unenlightened Muslim in duality with the enlightened Westerner. In this framing, the image also emphasises an Orientalist discourse.

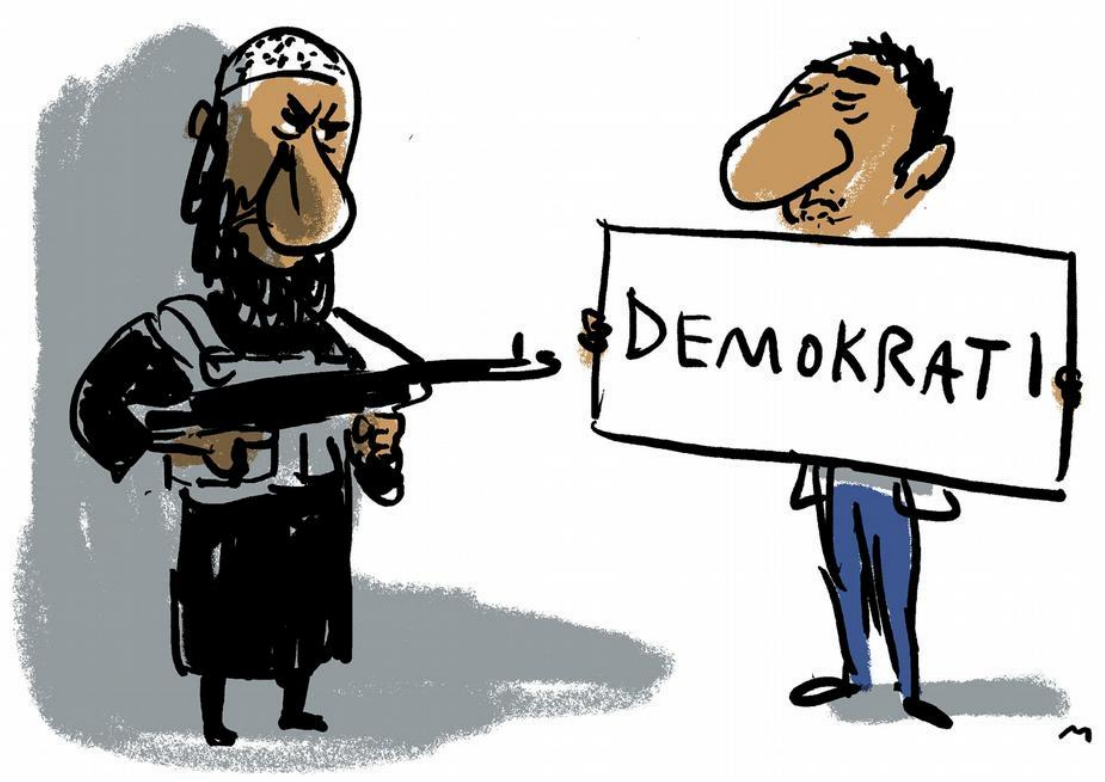

Image 3 Politiken, (Dreyer 2015)

This is a similar duality to that of The Telegraph and the use of videos showing the duality between Hamza and the cartoonist or the barbaric, angry 'foreign' Muslim versus the forgiving, enlightened West. 


\section{Conclusion}

This paper examined, cross-culturally, media discourses on Muslims in British and Danish newspapers following the Charlie Hebdo attack. The analysis demonstrates that discourses on Muslims are utilised within banal nationalism to construct Muslims implicitly as immigrants. Orientalist discourse references to Muslims having moved from another country into the 'host' nation. This is a similar finding to Baker et al. (2013) that Muslims and immigration are discursively linked in the media. Furthermore, Muslims are framed as being 'barbaric' and having different values from the 'host country'. Additionally, references to country 'values' and the liberal political elite function to criticise multiculturalism and multi-cultural visibility in both countries.

There is a focus on Islam as 'clashing' with the West; this is in binary opposition to the 'enlightened West', demarked as emotional, forgiving and liberal. All texts, irrespective of political leaning, utilise right-wing populist rhetoric through focusing on nationalism and 'the people' being under threat from Muslims. Terrorism is framed as 'allowed' and welcomed by the liberal political elite and discursively linked to 'threatened' freedom of speech and democracy in both countries (Freedman 2017). This reinforces the typical right-wing populist rhetoric, which concentrates on the construction of the political elite against the 'people' while 'pandering' to Muslim Others rights, neglecting the 'indigenous' (Stoica 2017). There is dominant use of right-wing populist discourse and focus on the differences in values. Thus, the incompatibility of Muslims in both countries is part of the 'cultural backlash' perspective used in right-wing populist rhetoric (Inglehart and Norris 2016). Muslims are represented as an Other, who are a security risk reinforcing Wodak et al.'s (2013) theory of the 'normalization' of Othering in politics, media and public discourse. This is in contrast to CheshmedzhievaStoycheva's (2015) finding of positive representation of Muslims following the Charlie Hebdo attack. However, this can be explained by the focus of this paper examining articles published within two weeks of the attack and the inclusion of more right-leaning newspapers, as well as left-leaning, in the analysis.

Furthermore, in the context of Gullestad's Star System theory, the paper identifies an extension of the theory in that a text including quotes from Muslims or ex-Muslims who criticise Islam or fellow Muslims, functions as part of the 'authority' to legitimize and normalise discourses and ideologies around Muslims. This was used in all texts except The Guardian. The findings outline that following the Charlie Hebdo attack, all newspapers utilised negative discourses framing and representing Muslims as a homogenous community linked to the terrorist attacks. 
The paper contributes to mediation research offering a further theoretical lens, through the Star System theory, to examine ways and tools which the media use to represent Muslims. Although the paper has limitations as it examined four texts, including three images, there is scope for expanding the corpus of texts. This could be achieved by employing mixed methods of quantitative content analysis on a larger corpus of texts and critical discourse analysis on selected texts.

\section{Future Research}

Future research should focus on utilising the Star System theory in Muslim media representation to examine how Star System members are utilised in different countries by the press as well as other media. Another interesting element for future research would be to focus on case study interviews of journalists about the production of news stories centred around the Charlie Hebdo attack. This would add a further contextual layer to a critical discourse analysis of the Charlie Hebdo attack.

\section{References}

Ahmed, S. and Matthes, J. (2017) 'Media representation of Muslims and Islam from 2000 to 2015: A meta-analysis', the International Communication Gazette, 79(3), 219 244

Alghamdi, E. A. (2015) 'The Representation of Islam in Western Media: The Coverage of Norway Terrorist Attacks', International Journal of Applied Linguistics \& English Literature, 4(3), 198-204

Allen, C. (2012) 'A review of the evidence relating to the representation of Muslims and Islam in the British media', Institute of Applied Social Sciences, University of Birmingham: UK

Allen, C. (2015) 'Britishness and Muslim-ness: differentiation, demarcation and discrimination in political discourse', Identity Papers: A Journal of British and Irish Studies, 1(2), 1 - 12

Andreassen, R. (2007) Det er et yndigt land - Medier, minoriteter og danskhed, Denmark: Tiderne Skifter

Baker, P., Gabrielatos, C. and Mcenery, T. (2013), Discourse Analysis and Media Attitudes: The Representation of Islam in the British Press, UK: Cambridge University Press

Benzehaf, B. (2017) 'Covering Islam in Western Media: From Islamic to Islamophobic Discourses', Journal of English Language Teaching and Linguistics, 2(1)

Bergström, A. and Belgrage, M. J. (2018) 'News in Social Media', Digital Journalism, 6(5), 583-598 
Bertelsen, B, E. Zagato, A. (2015) 'Introduction The Event of Charlie Hebdo Imaginaries of Freedom and Control', in The Event of Charlie Hebdo: Imaginaries of Freedom and Control, Oxford: Berghanh Books, pp. 1-12

Billig, M. (1995) Banal Nationalism, SAGE: UK

Bødker, H. (2009) 'Muslims in print, or media events as nodes of cultural conflict', in Marsden, L., Savigny, H. Media, religion and conflict, UK: Ashgate

Boe, C. (2017) 'From Jyllands-Posten to Charlie Hebdo: Domesticating the Mohammed Cartoons', in Titley, G., Freedman, D., Khiabany, G. and Mondon, A., (eds) After Charlie Hebdo Terror, Racism and Free Speech, UK: Zed Books, pp. 165180

Boreu, K. (2013) 'Nationalism and Discursive Discrimination against Immigrants in Austria, Denmark and Sweden', in Wodak, R., Khosravinik, M. and Mral, B (eds) RightWing Populism in Europe, UK: Bloomsbury Academic

Breeze, R. (2011) 'Critical Discourse Analysis and Its Critics', International Pragmatics Association, 21(4), $493-525$

Camre, M. (2015) 'Mens Vi Venter,' Available at: https://politiken.dk/debat/debatindlaeg/art5561674/Mens-vi-venter-p\%C3\%A5-detn\%C3\%A6ste-terrorangreb

Caviedes, A. (2015) 'An Emerging 'European' News Portrayal of Immigration?', Journal of Ethnic and Migration Studies, 41(6), 897-917

Cheshmedzhieva-Stoycheva, D. (2015) “Je Suis Muslim': The Image of Muslims In A Bulgarian and A British Newspaper', Lodz Papers in Pragmatics, 11(1), 105-126

Cihodariu, M. and Dumitrescu, L. S. (2013) 'The Motives and Rationalizations of the European Right-Wing Discourse on Immigrants. Shifts in Multiculturalism?', Journal of Comparative Research in Anthropology and Sociology, 2, 51 - 70

Dagistanli, S. and Grewal, K. (2012) 'Perverse Muslim masculinities in contemporary orientalist discourse: the vagaries of Muslim immigration in the West', in Morgan, $G$ and Poyntinh, S. Global Islamophobia: Muslims and Moral Panic in the West, England: Ashgate

Dominguez, V. R. (1994) 'A Taste for "the Other"', Current Anthropology, 35(4), 333 348

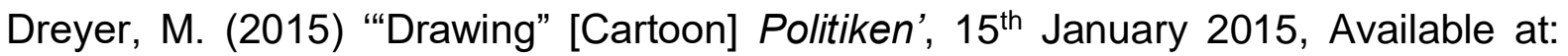
https://politiken.dk/debat/debatindlaeg/art5561674/Mens-vi-venter-p\%C3\%A5-detn\%C3\%A6ste-terrorangreb

Fairclough, N. (1989) Language and Power, UK: Routledge

Fairclough, N. (1992) Discourse and Social Change, UK: Polity Press

Fairclough, N. (2001) Language and Power (2nd ed), London: Longman 
Freedman, D. (2017) 'The Framing of The Charlie Hebdo Attacks', in Titley, G., Freedman, D., Khiabany, G. and Mondon, A., (eds), After Charlie Hebdo Terror, Racism and Free Speech, UK: Zed Books, pp. 209-223

Fryberg, S. A., Stephens, N. M., Covarrubias, R., Markus, H. R., Carter, E. D., Laiduc, G. A. and Salido, A. J. (2012) 'How the Media Frames the Immigration Debate: The Critical Role of Location and Politics', Analysis of Social Issues and Public Policy, 12(1), $96-112$

Gemi, E., Ulasiuk, I. and Triandafyllido, A. (2013) 'Migrants and Media Newsmaking Practices', Journalism Practice, 7(3), 266 - 281

Ghersetti, M. (2014) 'Still the Same?', Journalism Practice, 8(4), 373 - 389

Gullestad, M. (2006) Plausible Prejudice: Everyday Experiences and Social Images of Nation, Culture and Race, Norway: Universitetsforlaget

Hanes, E., Machin, S. (2014), 'Hate Crime in the Wake of Terror Attacks: Evidence From 7/7 and 9/11', Journal of Contemporary Criminal Justice, 30(3), 247-267

Hayton, R. (2010) 'Towards the Mainstream? UKIP and the 2009 Elections to the European Parliament', Politics, 30(1), 26-35

Hervik, P. (2002) 'Mediernes Muslimer - En antropologisk undersøgelse af mediernes dækning af religioner i Danmark', København: Institut for Menneskerettigheder

Hervik, P. (2012) 'Ending Tolerance as a Solution to Incompatibility: The Danish 'Crisis of Multiculturalism", European Journal of Cultural Studies, 15(2), 211 - 225

Hervik, P. (2014) The Annoying Difference: The Emergence of Danish Neonationalism, and Populism in the Post-1989 World (2nd ed), USA: Berghahn Books

Hervik, P. (2018) 'Ten Years after the Danish Muhammad Cartoon News Stories: Terror Radicalization as Predictable Media Events', Television \& Media, 19(2), 146154

Hjarvard, S., Lundby, K. (2018) 'Understanding Media Dynamics', in Lundby, K. (ed), Contesting Religion: The Media Dynamics of Cultural Conflicts in Scandinavia, Berlin: De Gruyter, pp. 51-65

Holtug, N. (2011) 'Nationalism, Secularism and Liberal Neutrality: The Danish Case of Judges and Religious Symbols', Diversity and the Liberal State, 6(2), 107 - 125

Inglehart, R. F. and Norris, P. (2016) 'Trump, Brexit, and the rise of Populism: Economic have-nots and cultural backlash', HKS Faculty Research Working Paper Series, Harvard University: USA, $1-52$

Jacobsen, S. J., Jensen, T. G., Vitus, K. and Weibel, K. (2013) 'Analysis of Danish Media setting and framing of Muslims, Islam and racism', Det Nationale Forskningscenter for Velfærd. SFI Working Paper, 10

Jensen, T. G. (2015) “Ghettoization' and 'parallel societies' in Denmark Public rhetoric and lived lives', in Righard, E., Johansson, M. and Salonen, T., Social Transformations 
in Scandinavian Cities: Nordic Perspectives on Urban Marginalization and Social Sustainability, Sweden: Nordic Academic Press:

Karim, K. (2011) 'Covering Muslims', in Zelizer, B. and Allen, S. Journalism After September 11, UK: Taylor \& Francis

Keskinen, S. and Andreassen, R. 2017, 'Developing Theoretical Perspectives on Racialisation and Migration', Nordic Journal of Migration Research, 7(2), 64 - 69

Kublitz, A. (2010) 'The Cartoon Controversy Creating Muslims in a Danish Setting', Social Analysis, 54(3), 107-125

Kuhn, R. and Nielsen, R. K. (2014) Political Journalism in Transition: Western Europe in a Comparative Perspective, London: I.B. Tauris

Lavrsen, L. and Kaae, M. (2015) 'Vi kan ikke bare lade, som om det ikke er muslimer', Available at:https://jyllandsposten.dk/protected/premium/international/ECE7349494/vi-kan-ikke-bare-lade-somom-det-ikke-er-muslimer

Lawrie, M. (2019) National Identity and Muslim "Immigrant" Representation in the British and Danish Press 2005 - 2015, PhD Thesis, UK, Robert Gordon University

Lesinka, M. (2014) 'The European backlash against immigration and multiculturalism', Journal of Sociology, 50(1), 37-50

Liu, J. and Shafi, A. (2019) 'Free speech versus marginalized groups: Public and newspaper responses to the Charlie Hebdo attack', Newspaper Research Journal, 40(2), 136-154

Meer, N., Varun, U. and Modood, T. (2015) 'Nationhood and Muslims in Britain' in Foner, N. and Simon, P (eds), Fear, Anxiety, Immigration and Belonging in North American and Western Europe, New York: Russell Sage Foundation, pp. 169-189

Moore, K., Mason, P., Mason, L. and Wren, J. M. (2008) 'Images of Islam in the UK: the representation of British Muslims in the national print news media 2000 2008', Available at: http://orca.cf.ac.uk/53005/1/08channel4-dispatches.pdf

Morey, P. and Yaqin, A. (2011) Framing Muslims Stereotyping and Representation after 9/11, USA: Harvard University Press

Nougayrede, N. (2015) After the Paris attacks we're in danger of abandoning the right to offend, Available at: https://www.theguardian.com/commentisfree/2015/jan/22/paris-attacks-right-tooffend

Pearson, A. (2015) 'When will the safety of innocent civilians - of all faiths and none - be put before the human rights of maniacs?' Available at: https://www.telegraph.co.uk/news/worldnews/europe/france/11345828/CharlieHebdo-When-will-the-safety-of-innocent-civilians-of-all-faiths-and-none-be-putbefore-the-human-rights-of-maniacs.html 
Poole, E. (2011) 'Change and Continuity in the Representation of British Muslims Before and After 9/11: The UK Context', Global Media Journal - Canadian Edition, $4(2), 49-62$

Poole, E. (2014), 'Muslim Media and the Politics of Representation: Media and Cultural Responses to Diversity Issues in Britain', Middle East Journal of Culture and Communication, 7(1)

Poole, E. and Richardson, J. E. (eds) (2006) Muslims and the News Media, UK: I.B. Tauris

Quandt, T. (2009) '(No) NEWS ON THE WORLD WIDE WEB? A comparative content analysis of online news in Europe and the United States', in Franklin, B. (ed) The Future of Newspapers, Oxon: Routledge, pp. 88 - 110

Qurashi, F. (2018) 'The Prevent strategy and the UK 'war on terror': embedding infrastructures of surveillance in Muslim communities', Palgrave Communications, 4(17), 1 - 13

Richardson, J. E. (2004) (Mis)representing Islam: The Racism and Rhetoric of British Broadsheet Newspapers, Amsterdam: John Benjamins Publishing:

Rytter, M. and Pedersen, M. H. (2014) 'A decade of suspicion: Islam and Muslims in Denmark after 9/11', Ethnic and Racial Studies, 37 (13), 2303 - 2321

Said, E. (1995) Orientalism, UK: Penguin

Said, E. (1997) Covering Islam: How the Media and the Experts Determine How We See the Rest of the World, USA: Vintage

Sheets, P., Bos, L. and Boomgaarden, H. (2015) 'Media cues and citizen support for right-wing populist parties', International Journal of Public Opinion Research, 28(3), $307-330$

Sian, K., Law, I. and Sayyid, S. 2012. The Media and Muslims in the UK, UK: Centre for Ethnicity and Racism Studies, University of Leeds

Sreberny, S. (2017) 'Mediated Narratives as Competing Histories of the Present', IN: Titley, G., Freedman, D., Khiabany, G. and Mondon, A., (eds), After Charlie Hebdo Terror, Racism and Free Speech, UK: Zed Books, pp. 192-209

Stoica, M. S. (2017) 'Political myths of the populist discourse', Journal for the Study of Religions and Ideologies, 46, 63 - 76

Stubbs, M. (1997) 'Whorf's children: Critical comments on critical discourse analysis' in Ryan, A. and Wray, A. (eds.), Evolving models of language, Clevedon: Multilingual Matters, pp. 100-116.

Sultan, K. (2016) 'Linking Islam with Terrorism: A Review of the Media Framing since 9/11', Global Media Journal, 1-9(2)

Talbot, M. (2007) Media Discourse: Representation and Interaction, UK: Edinburgh University Press 
Telegraph Media Group Limited (2015) 'The road to Abu Hamza's sentencing In 60 seconds', Available

at:

https://www.telegraph.co.uk/news/worldnews/europe/france/11345828/CharlieHebdo-When-will-the-safety-of-innocent-civilians-of-all-faiths-and-none-be-putbefore-the-human-rights-of-maniacs.html

van Dijk, T. A. (1992) 'Discourse and the Denial of Racism', Discourse \& Society, 3(1), 87-118

Vertovec, S. and Wessendorf, S. (eds) (2010), Multiculturalism Backlash: European Discourses, Policies and Practices, Oxon: Routledge

Vliegenthart, R. and Boomgaarden, H. G. (2007) 'Real-world indicators and the coverage of immigration and the integration of minorities in Dutch newspapers', European Journal of Communication, 22(3), 293 - 314

Weaver, S. (2010) 'Liquid Racism and the Danish Prophet Muhammad Cartoons', Current Sociology, 58(5), 675 - 692

Withnall, A. and Lichfield, J. (2015) 'Charlie Hebdo shooting: At least 12 killed as shots fired at satirical magazine's Paris office', Available at: https://www.independent.co.uk/news/world/europe/charlie-hebdo-shooting-10-killedas-shots-fired-at-satirical-magazine-headquarters-according-to-9962337.html

Wodak, R. (2015) The Politics of Fear, London: SAGE

Wodak, R., Khosravinik, M. and Mal, B. (2013) Right-Wing Populism in Europe, London: Bloomsbury

Yilmaz, F. (2011) 'The Politics of the Danish Cartoon Affair: Hegemonic Intervention by the Extreme Right', Communication Studies, 62(1), 5 -22

Michelle Lawrie has recently passed her PhD from the Robert Gordon University; her thesis focuses on national identity and Muslim representation in the British and Danish press. Michelle is interested in media research, hate crime, marginalised groups, representation theory, populism, far right groups, youth and gender.

Email: m.lawrie2@rgu.ac.uk 